\title{
Family functioning and health issues associated with codependency in families of drug users
}

\author{
Funcionamento familiar e questões de saúde \\ associados com codependência em familiares de usuários de drogas
}

Cassandra Borges Bortolon ${ }^{1}$

Luciana Signor ${ }^{1}$

Taís de Campos Moreira ${ }^{1}$

Luciana Rizzieri Figueiró ${ }^{1}$

Mariana Canellas Benchaya ${ }^{1}$

Cássio Andrade Machado ${ }^{2}$

Maristela Ferigolo ${ }^{1}$

Helena Maria Tannhauser Barros ${ }^{1}$

Departamento de

Farmacologia e Toxicologia

Universidade Federal de

Ciências da Saúde de Porto

Alegre. R. Sarmento Leite

245, Centro. 90050-170

Porto Alegre RS Brasil.

cassandra.bortolon@

gmail.com

${ }^{2}$ Grupo Hospitalar

Conceição.

\begin{abstract}
Substance abuse affects both the user and the family system as a whole, yet substance abuse treatment is centered on the user, leaving the family in the background. Objective: To identify the symptoms of codependency and health issues in the codependent family members of drug users who called a toll-free telephone counseling service. In total, 505 family members participated in this cross-sectional study. Drug users' mothers and wives who had less than 8 years of education and those who were unemployed had a greater chance of high codependency. It was also determined that a high level of codependency imposed a significant burden on the physical and emotional well-being of those affected, resulting in poor health, reactivity, self-neglect and additional responsibilities. It was concluded that codependency has a negative impact on the family system and on the health of the family members of drug users. Key words Codependency, Family, Drug users, Telephone
\end{abstract}

Resumo A dependência química atinge o usuário e o sistema familiar como um todo, todavia o tratamento dessa condição é centrado no usuário, o que deixa a família em segundo plano. Objetivo: identificar os sintomas de codependência e questões de saúde em familiares codependentes de usuários de drogas que ligaram para um serviço telefônico de aconselhamento. No total, 505 familiares participaram de um estudo transversal. Mães e esposas de usuários de drogas que tinham menos de 8 anos de estudo e que estavam desempregadas apresentaram maior chance de alta codependência. Além disso, foi identificado que o nivel alto de codependência interfere significativamente no bem-estar físico e emocional dos familiares, o que resultou em problemas de saúde, reatividade, autonegligência e sobrecarga de tarefas. Foi concluído que a codependência tem um impacto negativo no sistema familiar e na saúde dos familiares de usuários de drogas.

Palavras-chave Dependência mimética, Família, Usuários de drogas, Telefone 


\section{Introduction}

Drug dependence affects not only drug users themselves but all of the people in their social context, especially their family ${ }^{1}$. The lives of addicts' families usually focus on the family member's drug abuse, which can result in additional psychological problems ${ }^{2-4}$. Codependency refers to psychological behavioral problems that enable drug users and their family members to engage in mutually destructive habits and maladaptive coping strategies to maintain a sense of balance or homeostasis ${ }^{5}$. The wives of alcoholics report enabling their partners' use of alcohol and other drugs $^{6}$, and codependent family members display an intense need to help compared with family members without codependency ${ }^{7}$. Therefore, codependency may also be defined as a multidimensional problem influenced by a variety of factors that may begin in childhood with a compulsive need to assume a caretaker role and may produce paradoxical affective links that reinforce the drug user's maladaptive behavior patterns.

Codependent people compulsively maintain links with their children or partners despite the suffering and lack of compensation that characterize the relationships ${ }^{4}$. Codependent family members often have difficulty setting boundaries and asserting their own needs because of low self-esteem, poor emotional control and self-blame. This not only allows the drug user to continue their addiction but also prevents family members from seeking help for themselves and their loved ones ${ }^{4,8,9}$.

Known drug use within a family is an environmental stressor, and codependency may arise from these circumstances along with great psychological suffering ${ }^{10,11}$. Wives' descriptions of their alcohol-dependent husbands reveal their own physical and emotional overload in terms of responsibility for children and household maintenance, the performance of multiple roles in the family and financial worries ${ }^{12,13}$. The children of drug users present a higher risk of developing substance abuse and psychiatric disorders compared with children from families without substance abuse ${ }^{14}$. In addition to the increased mental health dysfunction ${ }^{15}$ associated with codependency, as seen in up to $59 \%$ of drug users' wives, there is an increased risk of physical disorders. One-fourth of the young women who seek general medical care in Mexico present with codependent behaviors, usually within a relationship with an alcohol-dependent partner ${ }^{4}$. Family members who seek telemedical help to deal with a family member who uses drugs present a poorer quality of life in the psychological and physical domains compared with the drug users themselves or with the general population ${ }^{16}$.

The codependency model is frequently used in health services for the joint treatment of drug and/or alcohol users and their families ${ }^{2,17}$. However, the substance abuse treatment is centered on the user, leaving the family in the background, and more studies that identify the main characteristics of the families of substance abusers are needed ${ }^{10,17}$. Nonetheless, the families of substance users need help, as family members present disorders that deserve greater attention from treatment programs ${ }^{12}$. This study aims to determine whether there is an association between family functioning and health issues and codependency in the families of drug users.

\section{Methods}

We conducted a cross-sectional study of 505 family members of drug users who had requested help with a drug user in the family by calling the drug-prevention information service "VIVAVOZ - call 132" and who requested information about treatment sites for drug users between August 2008 and March 2010.

The study was applied to the population of all five Brazilian regions. Parents, siblings, descendants, second- and third-degree relatives and spouses were included in this study (after they contacted the service). They completed assessments regarding codependency and family functioning. Incomplete protocols (the call was dropped, incomplete evaluation), family members of those who used only tobacco, individuals under 15 years of age and individuals who lacked the cognitive ability to answer the questionnaire were excluded. The research ethics committee of the Federal University of Health Sciences of Porto Alegre approved the project.

The data were collected by college students from different health areas who were trained in substance abuse problems and motivational interviewing (an intervention carried out in a follow-up telephone call) and who worked under the supervision of a licensed professional, as described elsewhere ${ }^{18}$. During the phone calls, the students collected sociodemographic data, codependency index information and answers to open-ended questions about family functioning. 


\section{Assessment of Codependency}

The instrument used to evaluate codependency was the Holyoake Codependency Index (HCI), a self-report instrument with 13-items that are rated on a 5-point Likert scale. Each of these 13 items falls into 1 of 3 themes (e.g., external focus, self-sacrifice and reactivity), and the average scores of the items in each theme are added to give a total score of 3 to 15 points ${ }^{2}$. External focus is characterized by focusing attention on the behavior, opinions and expectations of other people to gain their approval or affection; self-sacrifice refers to neglecting one's own needs to focus on meeting the needs of others; and reactivity reflects a belief in one's capacity to solve other people's problems and control their behavior ${ }^{2}$. The main characteristic of the HCI is that the self-report is based on the intensity of the dysfunctional link with drug users. The HCI was previously translated into Brazilian Portuguese, and scores higher than 9.7 determine high codependency ${ }^{19}$.

\section{Assessment of Family Functioning}

Telephone interviews were used to understand the individuals' family functioning. The interviews used strategies similar to those used in the clinical setting ${ }^{10,20}$. Family functioning was assessed using the participants' spontaneous self-responses to the prompt "Tell me how you perceive your relationship with the family member who uses drugs", based on the transcripts of telephone interviews with family members ${ }^{21}$.

The participants' responses were analyzed by a jury of two psychologists who received specific training from a psychologist who specialized in family psychology. The family specialist was also responsible for the final decision (based on the literature and experience with face-to-face interventions with the families of drug users) regarding the correct categorization when the jurors' opinions diverged. The answers were interpreted as binary variables (yes or no) for the following categories: 1- emotional/task overload, including descriptions of stress, fatigue, excessive worry, difficulty sleeping, loss of emotional control and poor crisis management resulting from the user's behavior and the added burden of paying the user's debts, theft of personal property and the use of drugs in the household; 2- self-neglect, focusing on user's need instead of one's own, neglect of personal and professional responsibilities, covering for the user's inappropriate behavior, accepting drug use in the home and failing to establish boundaries and implement changes; and 3- personal health issues, based on descriptions of seeking treatment for medical, psychological and psychiatric conditions and participation in self-help groups.

\section{Data Analysis}

Data analysis was conducted using the Statistical Package for the Social Sciences (SPSS) program, version 18.0. Initially, univariate analyses of categorical variables were conducted using the Chi-squared test, odds ratios (OR) and the confidence interval $(95 \% \mathrm{CI})$. The variables of the respondent's relationship with the drug user, sex, profession, family income and education were included in the logistic regression analysis. Statistical significance was set at $\mathrm{p}<0.05$.

\section{Results}

Among the 505 family members who were interviewed, $64 \%$ showed high codependency according to the HCI scale. The sample was composed mainly of women who were the mothers or wives of drug users. The sociodemographic characteristics of the family members are presented in Table 1. Mothers and wives were unemployed and those with less than 8 years of education were likely to exhibit high codependency. The association between the sociodemographic variables and the codependency level is presented in Table 2.

The most common Brazilian states from which the families sought help were as follows: Rio Grande do Sul (37.1\%), São Paulo (15\%), Rio de Janeiro (9.9\%), Minas Gerais (7.3\%), Bahia (5.9\%), Paraná (5.5\%), Distrito Federal (3.6\%), Santa Catarina (2.6\%); and $13.1 \%$ came from the remaining states.

A descriptive analysis of the 3 codependency themes of the HCI among family member revealed that external focus occurred very infrequently, while self-sacrifice (52\%) and reactivity (59\%) were relatively common. According the HCI, the only element that predicted high codependency was reactivity (OR 2.33, 95\% CI $=1.55-3.49$ ). Self-sacrifice, on the other hand, predicted low rather than high codependency (OR 0.58, 95\% CI $=0.39-0.86$ ). A descriptive analysis of family functioning showed that the family members who called the hotline exhibited emotional/task overload (88\%) and self-neglect (75\%). 


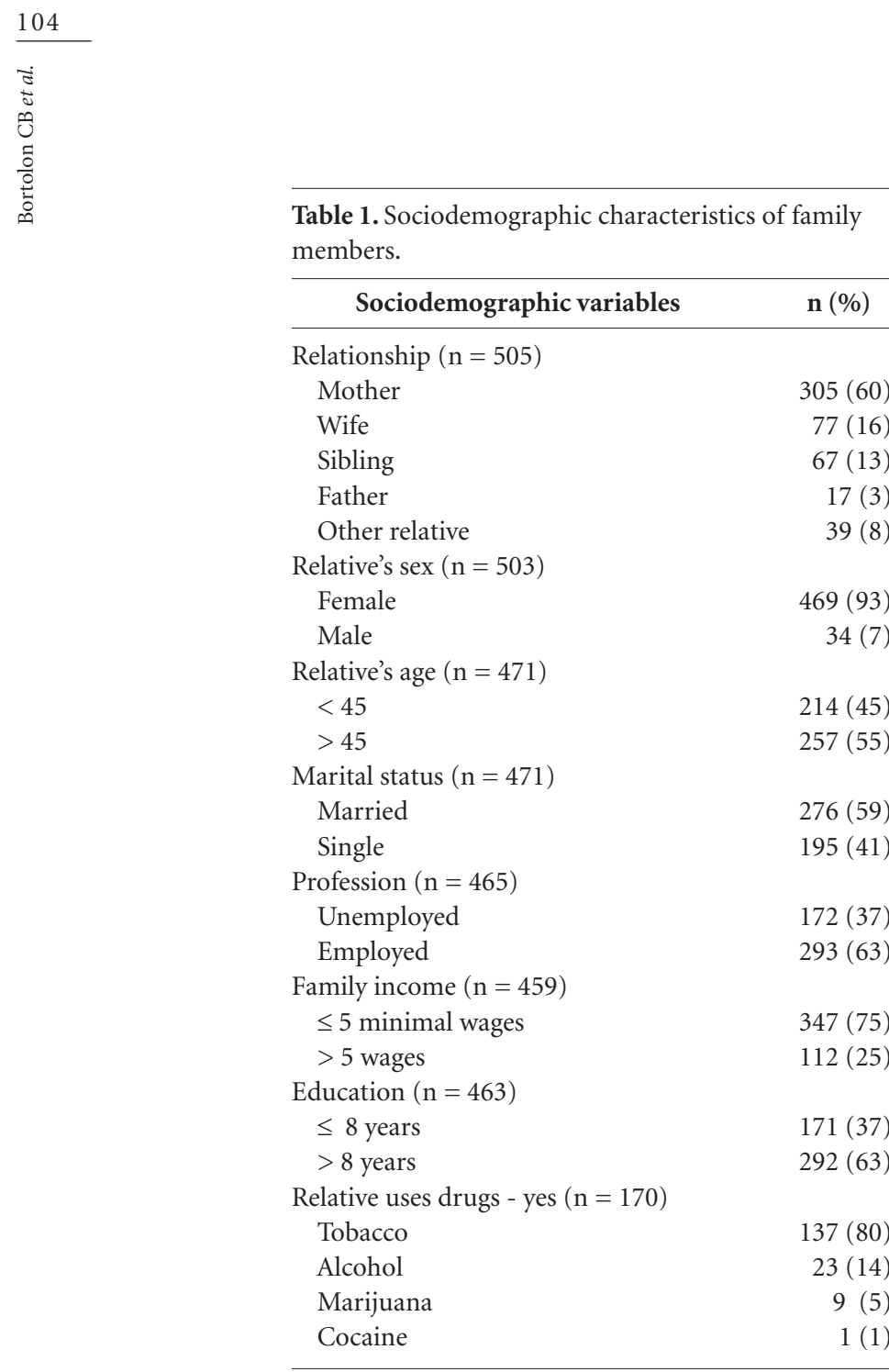

A high proportion of the family members who called to discuss how to help someone who used drugs reported that their own medical condition was unhealthy $(47 \%)$. In particular, the family members reported seeking medical treatment for themselves (33\%), using medication (39\%), participating in self-help groups (19\%) and enrolling in psychological or psychiatric treatments (22\%). Among the highly codependent participants, $69 \%$ reported that they were receiving medical treatment, compared with $31 \%$ of the low-codependency group. Medication was used by $70 \%$ of the high-codependency participants and by $29 \%$ of the low-codependency participants. Psychological/psychiatric treatments were reported by $65 \%$ of the high-codependency participants and by $35 \%$ of the low-codependency participants. Bivariate analysis showed that high codependency (OR 1.57, 95\% CI $=1.04$ -
2.35) was associated with medical treatment. The only significant predictor of high codependency in the family members of drug users after the logistical regression was medication use (OR 1.54, $95 \%$ CI $=1.01-2.35)$, as Table 3 shows.

\section{Discussion}

This study showed that the majority of the family members who called the drug-related toll-free number exhibited high levels of codependency. Other studies have also revealed a high risk of codependency among women whose husbands or fathers had alcohol use problems $s^{2,419}$. These results corroborate the reports that wives and mothers who are bonded with a person who does little to solve his/her own problems suffer from emotional conflicts, tension and preoccupation with the user's excessive alcohol consumption and maladaptive behaviors ${ }^{4,22}$. This study also shows that the family members of drug users with high codependency present dysfunctional behaviors and receive more medical treatment, including more drug prescriptions. In fact, a study of Mexican women seeking primary health care showed a codependency rate of $25 \%$, with a much higher likelihood of codependency among women whose partners or fathers presented alcohol dependence ${ }^{4}$. Both studies reflect the need to better comprehend how family relationships interconnect with mental and physical health and how they relate to the diagnosis of codependency in women who are treated at primary health care units.

In our study, the HCI characteristic of high reactivity was associated with codependency. This characteristic indicates that the wife or mother takes on responsibilities that are not her own, and consequently, the drug user never realizes the consequences of his own addiction ${ }^{1,2,19}$. These highly reactive family members have limited insight into the effects of their attitudes toward the drug user; hence, they engage in enabling behaviors that thwart any efforts to improve the drug user's condition ${ }^{6}$.

Using the spontaneous self-reports, it was possible to gather further details about the family functioning associated with high codependency. Codependent family members exhibit a need to care for and control the behavior of the drug users, which leads to physical and emotional overload and the neglect of their own needs ${ }^{1,19}$. Self-neglect was almost three times more likely to occur in family members with high codependency than in those with low codependency. 


\begin{tabular}{|c|c|c|c|c|}
\hline Sociodemographic data & $\begin{array}{c}\text { High } \\
\text { codependency } \\
\text { n }(\%)\end{array}$ & $\begin{array}{c}\text { Low } \\
\text { codependency } \\
\mathbf{n}(\%)\end{array}$ & $\begin{array}{c}\text { OR }(95 \% \text { IC }) \\
\text { Bivariate }\end{array}$ & $\begin{array}{c}\text { OR (95\% IC) } \\
\text { Adjusted }\end{array}$ \\
\hline \multicolumn{5}{|l|}{ Relationship (n = 505) } \\
\hline Parents and wives & $257(80)$ & $125(68)$ & $1.89(1.25 \mathrm{a} 2.86)^{*}$ & $1.90(1.23 \text { a } 2.93)^{*}$ \\
\hline Other & $64(20)$ & $59(32)$ & 1.0 & 1.0 \\
\hline \multicolumn{5}{|l|}{ Relative's sex ( $\mathrm{n}=503$ ) } \\
\hline Female & $305(96)$ & $164(89)$ & $2.65(1.30 \text { a } 5.39)^{*}$ & $1.39(0.60$ a 3.21$)$ \\
\hline Male & $14(4)$ & $20(11)$ & 1.0 & 1.0 \\
\hline \multicolumn{5}{|l|}{ User's sex $(n=503)$} \\
\hline Male & $298(93)$ & $172(93)$ & $0.99(0.47$ a 2.06$)$ & \\
\hline Female & $21(7)$ & $12(7)$ & 1.0 & \\
\hline \multicolumn{5}{|l|}{ Relative's age $(\mathrm{n}=471)$} \\
\hline$\geq 45$ years old & $140(48)$ & $74(42)$ & $1.24(0.85$ a 1.81$)$ & \\
\hline$<45$ years old & $155(52)$ & $102(58)$ & 1.0 & \\
\hline \multicolumn{5}{|l|}{ User's age $(\mathrm{n}=489)$} \\
\hline$\geq 45$ years old & $13(4)$ & $7(4)$ & $1.10(0.43$ a 2.82$)$ & \\
\hline$<45$ years old & $294(96)$ & $175(96)$ & 1.0 & \\
\hline \multicolumn{5}{|l|}{ Marital status $(\mathrm{n}=471)$} \\
\hline Married & $177(59)$ & $99(58)$ & $1.07(0.73$ a 1.56$)$ & \\
\hline Single & $122(41)$ & $73(42)$ & 1.0 & \\
\hline \multicolumn{5}{|l|}{ Profession $(\mathrm{n}=465)$} \\
\hline Unemployed & $120(41)$ & $52(30)$ & $1.60(1.07 \text { a } 2.38)^{*}$ & $1.64(1.07 \text { a } 2.52)^{*}$ \\
\hline Employed & $173(59)$ & $120(70)$ & 1.0 & 1.0 \\
\hline \multicolumn{5}{|l|}{ Family income $(\mathrm{n}=459)$} \\
\hline$\leq 5$ minimum wages & $229(79)$ & $118(69)$ & $1.74(1.13 \text { a } 2.68)^{*}$ & $1.29(0.81$ a 2.06$)$ \\
\hline$>5$ wages & $59(21)$ & $53(31)$ & 1.0 & 1.0 \\
\hline \multicolumn{5}{|l|}{ Education $(\mathrm{n}=463)$} \\
\hline$\leq 8$ years & $125(43)$ & $46(27)$ & $2.00(1.33 \text { a } 3.02)^{*}$ & $1.72(1.12 \text { a } 2.64)^{*}$ \\
\hline$>8$ years & $168(57)$ & $124(73)$ & 1.0 & 1.0 \\
\hline \multicolumn{5}{|l|}{ Relative uses drugs $(\mathrm{n}=404)$} \\
\hline Yes & $108(34)$ & $62(34)$ & $0.99(0.67$ a 1.46$)$ & \\
\hline No & $206(66)$ & $118(66)$ & 1.0 & \\
\hline
\end{tabular}

Mothers (51.1\%) and fathers (3.1\%); wives (45.8\%). Multivariate analysis: adjustment for relationship, profession, and education. " $\mathrm{p}<0.05$.

High-codependency individuals are controlled by the user's behavior; they allow it to affect their personal and occupational lives by changing or cancelling plans, hiding the user's behavior from the rest of the family, lying or excusing the user's behavior, and expressing a desire to change their own behavior without managing to do so ${ }^{6}$.

Self-sacrifice is an important behavioral trait; it reflects a tendency to place others' needs above one's own. Self-sacrifice has been previously reported as a common trait among Brazilian family members regardless of their codependency classification $^{19}$; this finding is in contrary to the findings of studies from the Northern hemisphere, and the differences may be attributed to cultural differences ${ }^{2}$. It is important to consider cultural issues in the Brazilian population with regard to traditional women's roles and family dedication, responsibility and "unconditional love", which may manifest as servile and self-sacrificing behaviors. Because of high reactivity and self-neglect, emotional/task overload is common among high-codependency family members and may increase the risk of psychological and physical disorders.

The limitations of this study are mainly related to the fact that family functioning was evaluated using self-reports; the family members may have underreported or minimized behavioral outcomes that are considered normal within the 


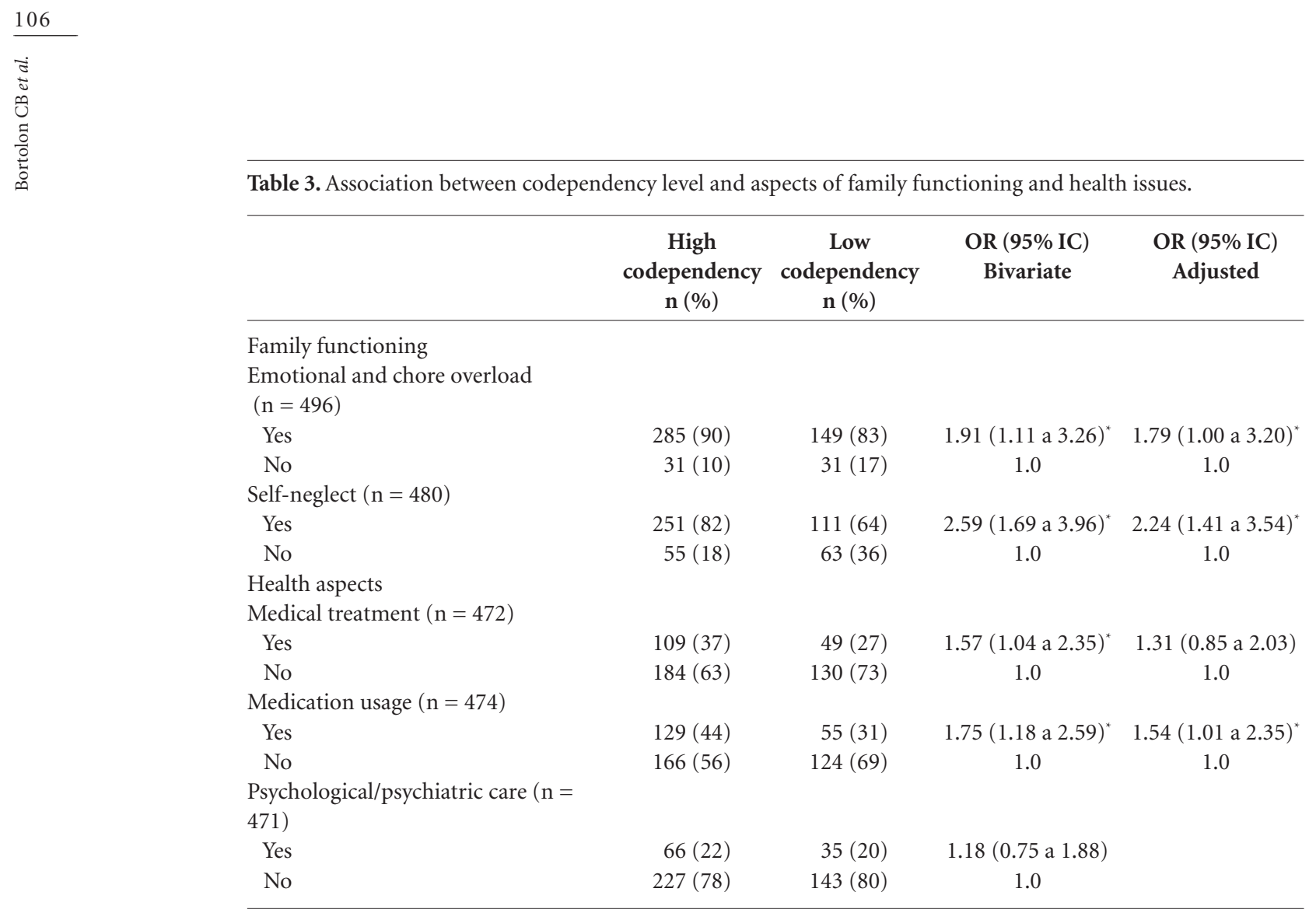

Multivariate analysis: adjustment for relationship, profession, and education. ${ }^{~} \mathrm{p}<0.05$.

family setting. Additionally, the interview instrument was developed internally and was not validated. Some limitations regarding health issues need to be considered; specifically, we did not have access to the participants' medical records and relied on self-reports of the described problems. The classification of a family member as a "drug user" was based only on the telephone accounts of the informants themselves, who were the family members of the user. Future research should be planned to overcome these limitations.

This study described family functioning and codependency and health issues in the family members of drug users. The family scenario surrounding substance abuse creates unnecessary suffering for the family members as a result of the effects of addiction ${ }^{16,23}$. These data may be utilized in clinical settings, where codependency should be diagnosed and treatment programs directed toward the family members of drug users should include medical and psychological inter- ventions. In conclusion, there is an urgent need to establish appropriate care and effective interventions for the family members of drug users.

\section{Collaborations}

CB Bortolon, HMT Barros and M Ferigolo participated in the design of this study. CB Bortolon, MC Benchaya, CA Machado and L Signor. conducted a literature review and discussion. CB Bortolon, TC Moreira and LR Figueiró conducted a statistical analysis. All of authors participated in the review and reading in full of this article. 


\section{References}

1. Denning P. Harm reduction therapy with families and friends of people with drug problems. J Clin Psychol 2010; 66(2):164-174.

2. Dear G, Roberts C. The validation of the holyoake codependency index. J Psychol 2005; 139(4):293-313.

3. Daire AP, Jacobson L, Carlson RG. Emotional Stocks and Bonds: a metaphorical model for conceptualizing and treating codependency and other forms of emotional overinvesting. Am J Psychother 2012; 66(3):259278.

4. Noriega G, Ramos L, Medina-Mora ME, Villa AR. Prevalence of codependence in young women seeking primary health care and associated risk factors. Am J Orthopsychiat 2008; 78(2):199-210.

5. Steinglass P. Systemic-motivational therapy for substance abuse disorders: an integrative model. J Fam Ther 2009; 31(2):155-174

6. Rotunda R, West L, O'Farrel T. Enabling behavior in a clinical sample of alcohol-dependent clients and their partner. J Subst Abuse Treat 2004; 26(4):269-279.

7. Gómes A, Delgado D. La codependencia en familias de consumidores y no consumidores de drogas: estado del arte y construcción de un instrumento. Psicothema 2003; 15(3):381-387.

8. Doba K. Nandrino JL Dodin V, Antoine P. Is there a family profile of addictive behaviors? Family functioning in anorexia nervosa and drug dependence disorder. J Clin Psychol 2014; 70(1):107-117.

9. Beattie M. The new codependency: help and guidance for today's generation. New York: Simon \& Schuster; 2009.

10. Yandoli D, Eister I, Robbins C, Mullady G, Daire C. A comparative study of family therapy in the treatment of opiate users in a London clinic. J Fam Ther 2002; 24(4):402-422.

11. Fuller J, Warner R. Family stressors as predictors of codependency. Genet Soc Gen Psychol Monogr 2000; 126(1):5-22.

12. Laranjeira R, Sakiyama H, Padin MF, Mitsuhiro S, Madruga C. Levantamento Nacional de Famílias de Dependentes Químicos. 2013 Dez (Lenad Famílias): UNIAD, INPAD, CNPQ. [cited $2014 \mathrm{dez}$ 15]. Available from: http://www.inpad.org.br/lenadfamilia.

13. Peled E, Sacks I. The self-perception of women who live with an alcoholic partner: dialoging with deviance, strength, and self-fulfillment. Fam Relat 2008; 57(3):390-403.
14. Figlie N, Fontes A, Moraes E, Payá R. Filhos de dependentes químicos com fatores de risco psicossociais: necessitam de um olhar especial? Rev Psiq Clín 2004; 31(2):53-62.

15. Oxford J, Velleman R, Natera G, Templeton L, Copelo A. Addiction in the family is a major but neglected contributor to the global burden of adult ill-health. Soc Sci Med 2013; 78:70-77.

16. Moreira TC, Rizzieri LF, Fernandes S, Justo FM, Dias IR, Barros HMT, Ferigolo M. Qualidade de vida em usuários de substâncias psicoativas, familiares e não usuários por meio do WOOQOL BREF. Cien Saude Colet 2013; 18(7):1953-1962.

17. Sparks SN, Tisch R, Gardner M. Family-centered intervention for substance abuse in Hispanic Communities. J Ethn Subst Abuse 2013; 12(1):68-81.

18. Barros HMT, Santos V, Mazoni CG, Dantas DCM, Ferigolo M. Neuroscience education for health profession undergraduates in a call-center for drug abuse prevention. Drug Alcohol Depend 2008; 98(3):270-274.

19. Bortolon CB, Ferigolo M, Grossi R, Kessler FH, Barros HMT. Avaliação das crenças codependentes e dos estágios de mudança em familiares de usuários de drogas que ligaram para um serviço de teleatendimento. Rev AMRIGS 2010; 54(4):432-436.

20. Fischer CJ, Griffiths H. Family therapy with problem drinkers and drug takers: a pilot follow-up study. J Fam Ther 1990; 12(2):183-188.

21. Bardin L. Análise de conteúdo. $6^{\mathrm{a}}$ ed. Lisboa: Edições 70; 2011.

22. Hunt G. "The too-good wife": alcohol, codependency, and politics of nurturance in Postwar Japan. Am Ethnol 2008; 35(3):3038-3041.

23. Schenker M, Minayo MCS. A implicação da família no uso abusivo de drogas: uma revisão crítica. Cien Saude Colet 2003; 8(1):299-306.

Artigo apresentado em 18/06/2014

Aprovado em 30/04/2015

Versão final apresentada em 02/05/2015 